\title{
Production of Defense Phenolics in Tomato Leaves of Different Age
}

\author{
Kateřina Dadáková *(i), Tereza Heinrichová, Jan Lochman and Tomáš Kašparovský(i) \\ Department of Biochemistry, Faculty of Science, Masaryk University, Kotlářská 2, 61137 Brno, Czech Republic; \\ 474184@mail.muni.cz (T.H.); jlochman@seznam.cz (J.L.); tkasp@sci.muni.cz (T.K.) \\ * Correspondence: 147047@mail.muni.cz
}

Academic Editors: Sławomir Dresler and Barbara Hawrylak-Nowak

Received: 25 September 2020; Accepted: 26 October 2020; Published: 26 October 2020

\begin{abstract}
Phenolics play an essential role in the defense reaction of crop plants against pathogens. However, the intensity of their production induced by infection may differ during the life of a plant. Here, we identified age-related differences in phenolic biosynthesis in the pathosystem Solanum lycopersicum cv. Amateur and Pseudomonas syringae pv. tomato DC3000. We analyzed concentrations of total phenolics, phenolic profiles, and concentrations of selected phenolic acids. The influence of bacterial infection, together with leaf and plant age, was assessed. The changes in concentrations of caffeic acid, 4-hydroxybenzoic acid, and salicylic acid glucoside caused by infection were found to be influenced by age. In concrete, the increases in the concentrations of these metabolites were all evident only in young plants.
\end{abstract}

Keywords: tomato; phenolics; defense compounds; bacterial infection; plant age; leaf age

\section{Introduction}

Plants are exposed to a range of pathogenic organisms, including bacteria, fungi, and viruses, resulting in infections and substantial reductions in crop yields. Modern methods of crop protection often exploit the natural plant defense reaction against pathogens, allowing for reducing the amounts of pesticides contained in foodstuffs and released into the environment [1,2]. Plant defense-related metabolites accumulate due to defense stimulation or infection and influence the quality of harvested plant products [3]. Therefore, studying the defense reaction and defense-related secondary metabolites of crop plants is of great importance.

Among the defense-related secondary metabolites, phenolics play an essential role throughout the plant kingdom. Due to their chemical structure, they act primarily as antioxidants and accumulate in the tissues, especially in the cases of microbial infections connected with oxidative stress [4]. Following reaction with a radical during oxidative stress, hydroxyl groups attached to aromatic rings enable phenolic compounds to be converted to stable radical forms, terminating the production of new reactive species [5]. Furthermore, phenolic compounds play important roles in repelling pathogens and pests, and many phenolics possess direct antimicrobial properties [6].

The concentrations of phenolics in plant tissues are known to increase in response to infections by microbial pathogens [6]. Phenylalanine ammonia-lyase, a key enzyme of phenolic synthesis, is commonly induced during the so-called pattern-triggered immunity, which is activated after the recognition of a microbe-associated molecular pattern [7]. Apart from this basal resistance, phenolics are also involved in specific interactions between host plants and their pathogens, including tomato defense against bacterium Pseudomonas syringae pv. tomato DC3000. In resistant tomato cultivars, recognition of the P. syringae bacterium leads to induction of the phenylpropanoid pathway and this way to cell wall lignification and thickening, as well as to enhanced synthesis of anthocyanins and other antioxidants [8]. 
However, the content of phenolics in plants is dynamic and changes according to environmental and developmental conditions [6,9]. In crop plants, phenolics content in leaves somewhat decreases with age, likely because of the decrease in photosynthate supply during leaf maturation [10-13]. This trend was generally confirmed in tomato, but different phenolic compounds followed different patterns during leaf development and aging [9].

The aim of this study was to identify age-related differences in the phenolic biosynthesis in the well-described model pathosystem Solanum lycopersicum cv. Amateur and Pseudomonas syringae pv. tomato DC3000. For the first time, we have summarized the age-related differences in the biosynthesis of defense phenolics in tomato and described the identified changes in the contents of phenolic acids.

\section{Results and Discussion}

\subsection{Total Phenolic Contents}

Total concentrations of phenolics determined by the reaction with Folin-Ciocalteu reagent ranged between 20 and $70 \mu \mathrm{g}$ of gallic acid equivalents (GAE) per $1 \mathrm{~mL}$ of leaf extract (0.8-2.8 mg GAE/g of leaf DW, Table 1). Generally, the mean concentrations of phenolics were lower in control than in infected leaves, but these differences were not statistically significant $(p>0.2)$. This observation could be explained by simultaneous production of phenolics and their transformation into more antimicrobial compounds during defense reaction, as suggested in an earlier study on tomato leaves [14]. In previous studies, the leaf extracts from tomato plants displayed contents between 6 and $130 \mathrm{mg}$ GAE/g of the dried extract [15,16] or 160-240 mg GAE/g of leaf DW [17]. The wide range of phenolic concentration values found in leaves is likely caused by natural variations connected to the different genetic background as well as to the developmental and environmental conditions of studied plants.

Table 1. Total concentrations of phenolics expressed as gallic acid equivalents. Data are presented as means \pm standard deviations of three biological replicates. Statistical significance was determined using factorial ANOVA, the same letter (a) indicates no significant differences.

\begin{tabular}{cccc}
\hline \multirow{2}{*}{ Total Phenolics $(\mu \mathrm{g} / \mathrm{mL})$} & Young Plants & \multicolumn{2}{c}{ Old Plants } \\
\cline { 2 - 4 } & Young Leaves & Young Leaves & Old Leaves \\
\hline Control & $27 \pm 6(\mathrm{a})$ & $20 \pm 6(\mathrm{a})$ & $44 \pm 14(\mathrm{a})$ \\
Infected & $48 \pm 4(\mathrm{a})$ & $35 \pm 8(\mathrm{a})$ & $70 \pm 15(\mathrm{a})$ \\
\hline
\end{tabular}

\subsection{Phenolic Profiles}

Phenolic compounds and compounds from biosynthetic pathways of phenolics were detected in leaf extracts by LC-MS. In total, 37 metabolites were putatively identified by comparison of obtained mass spectra with database records (Table S1). Differences in the obtained phenolic profiles were visualized by principal component analysis (PCA) (Figure 1). The 2D visualization shows that component 1 separates the samples according to the plant age, component 2 separates the samples according to the leaf age, and component 3 separates control and infected samples, primarily in young plants. The PCA loadings (Table S1) indicate that component 1 includes primarily compounds putatively identified as benzoic, syringic, 4-hydroxybenzoic, and ellagic acids, all with negative coefficients; their amounts seem to decrease with increasing plant age (Figure 1). Component 2 includes primarily compounds putatively identified as kaempferol derivatives, again with negative coefficients. The last component 3 includes compounds putatively identified as ferulic and chlorogenic acids with negative coefficients and flavonoid derivatives rutin and kaempferol glycoside with positive coefficients; their amounts seem to decrease with infection. 


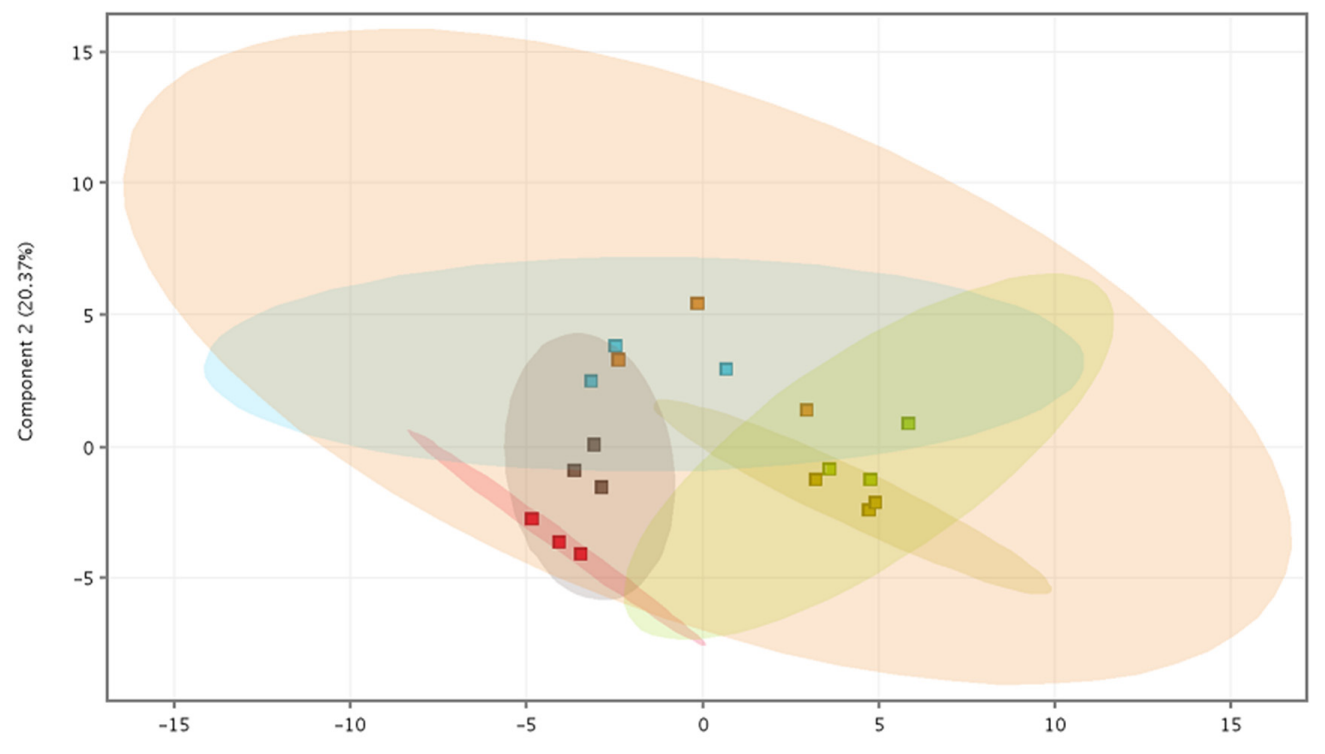

Component $1(38.2 \%)$
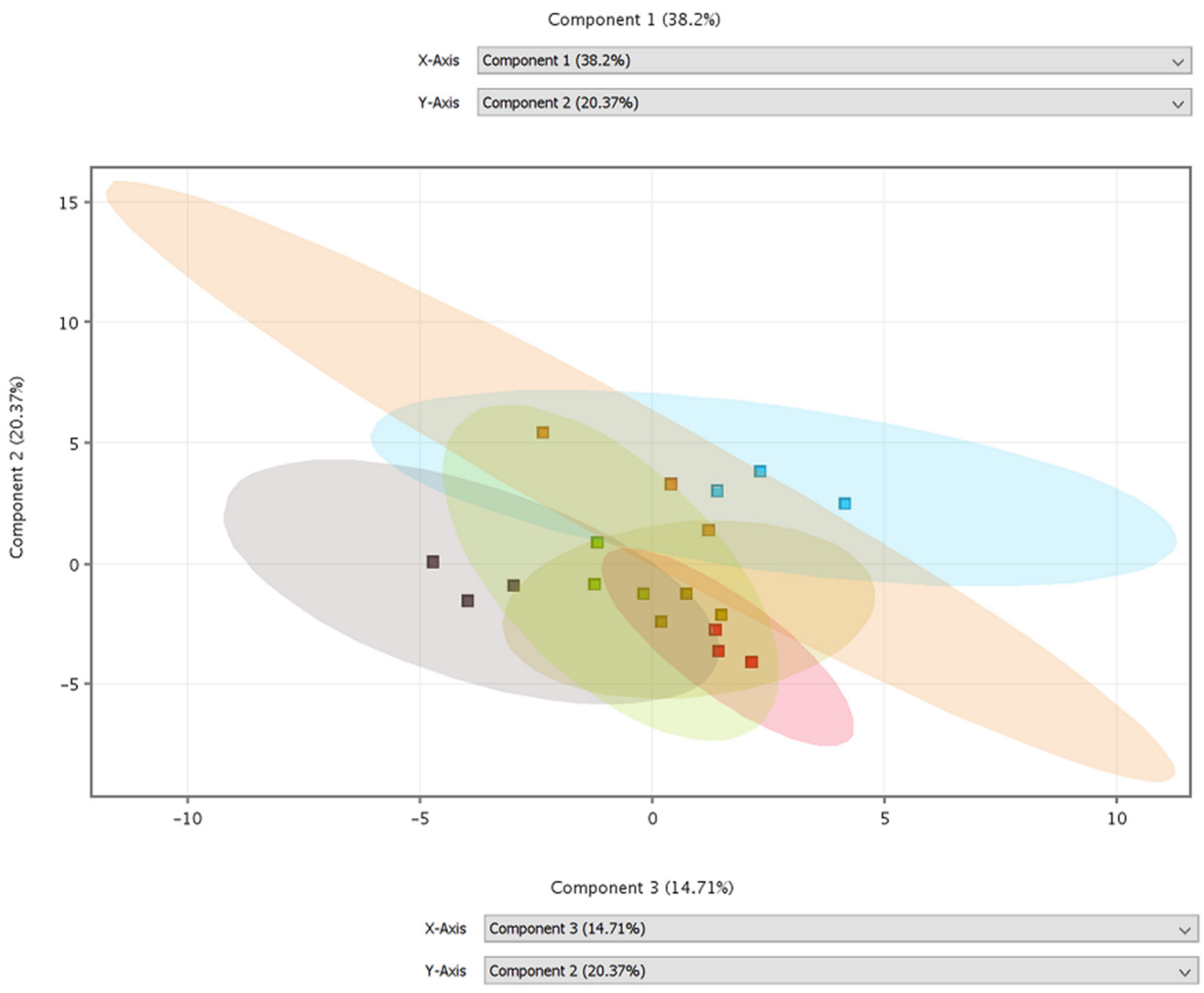

- Young control leaves from young plants

- Young infected leaves from young plants

- Young control leaves from old plants

" Young infected leaves from old plants

- Old control leaves from old plants

- Old infected leaves from old plants

Figure 1. 2D visualization of principal component analysis (PCA) using the first three components. Different samples (three biological replicates per variant) are shown in different colors. 


\subsection{Concentrations of Selected Phenolic Acids}

Based on the PCA results, phenolic acids, their precursor, and derivatives were analyzed in detail (Figure S1). Phenolic acids serve as precursors for many important metabolites influencing the plant fitness. They can be classified as derivatives of benzoic and cinnamic acids (Figure 2) [18]. Among benzoic acid derivatives, the plant hormone salicylic acid is probably the most important metabolite concerning the defense reaction against pathogens. In plants, it is synthesized either from chorismate by isochorismate synthase (ICS) pathway or by phenylalanine ammonia-lyase (PAL) pathway, including benzoic acid 2-hydroxylase $[19,20]$. The importance of these pathways for the biosynthesis of salicylic acid differs in plant species.<smiles>O=C(O)/C=C/c1ccccc1</smiles><smiles></smiles><smiles>O=C(O)c1ccccc1</smiles>

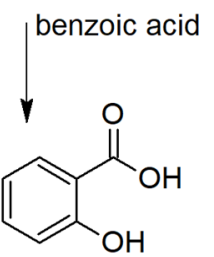

salicylic acid<smiles>O=C(O)/C=C/c1ccc(O)cc1</smiles><smiles>O=C(O)/C=C/c1ccc(O)c(O)c1</smiles><smiles>COc1cc(/C=C/C(=O)O)ccc1O</smiles><smiles>O=C(O)c1ccc(O)cc1</smiles>

4-hydroxybenzoic acid

Figure 2. Biosynthetic relations between the studied phenolic acids.

The comparison of retention times with those of analytical standards showed that chlorogenic and ellagic acids had been misidentified. Benzoic, caffeic, ferulic, 4-hydroxybenzoic, and syringic acid were correctly identified and quantified (Figure 3).

Among the analytes, the concentration of syringic acid was significantly influenced neither by age nor by $P$. syringae infection (Figure 3E). Other analytes were influenced by both age $(p<0.001$ for benzoic, caffeic, hydroxybenzoic, and ferulic acids) and infection $(p=0.011, p=0.002, p<0.001$, and $p<0.001$ for benzoic, caffeic, 4-hydroxybenzoic, and ferulic acid, respectively), or also by their interaction ( $p=0.002$ and $p<0.001$ for caffeic and 4-hydroxybenzoic acid, respectively; Figure 3A-D).

According to the age effect, the studied phenolic acids can be divided depending on whether there is a difference between plants of different ages or between leaves of different ages. The concentration of benzoic acid was significantly higher in young healthy plants than in old healthy plants and also in young infected plants than in young leaves of old infected plants. The concentration of 4-hydroxybenzoic acid was significantly higher in young infected plants than in old infected plants. On the other hand, the concentration of ferulic acid was significantly higher in young healthy leaves than in old healthy leaves of old plants. The concentration of caffeic acid was significantly higher in young healthy leaves from old plants than in old healthy leaves from old plants. Furthermore, the concentration of caffeic acid was significantly higher in infected young leaves from young plants than in both types of infected leaves from old plants (Figure 3). In a previous study on tomato leaves, two phenolic compounds were putatively identified, caffeic acid glucoside and rutin [9]. Caffeic 
acid glucoside showed a decrease in content with increasing leaf age, in concordance with the result reported here. Moreover, in this study, the content of other phenolic acids was found to decrease with the age of the tissue.

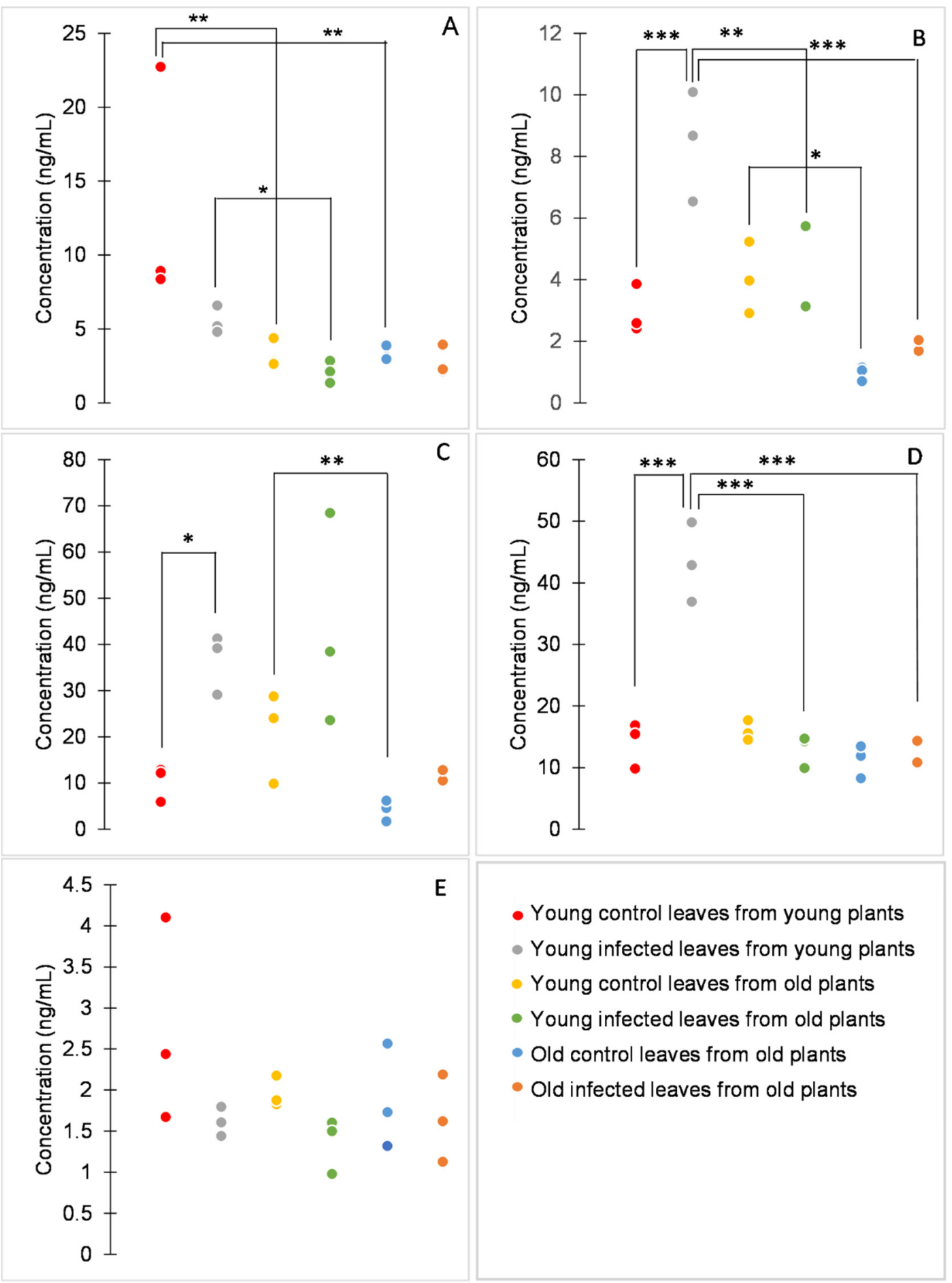

Figure 3. Concentrations of benzoic (A), caffeic (B), ferulic (C), 4-hydroxybenzoic (D), and syringic acid (E). Dot plots display all data points (three biological replicates per variant). $p$ values were determined using factorial ANOVA, ${ }^{*}$ indicates $p \leq 0.05,{ }^{* *}$ indicates $p \leq 0.01,{ }^{* * *}$ indicates $p \leq 0.001$. For better clarity, only statistically significant differences between samples of either the same age or the same infection status are shown. 
Concerning the infection effect, the concentrations of caffeic, ferulic, and 4-hydroxybenzoic acids tended to be higher in infected than in healthy tissues, concordant with previously reported results [21-23]. However, the effect was evident only in young plants. Ferulic acid and its precursor caffeic acid have been studied for their antimicrobial properties [24,25]. Moreover, increased concentration of caffeic acid has been associated with tomato response to bacterial pathogens and with enhanced resistance against $P$. syringae [26,27]. Therefore, it is not surprising that these phenolic acids are synthesized in tomato leaves in response to this pathogen.

Furthermore, a compound putatively identified as salicylic acid glucoside was significantly influenced by infection, age, and their interaction $(p=0.020, p<0.001$, and $p<0.001$, respectively). In concrete, the amount of this compound was significantly higher in young infected leaves of young plants than in all other samples $(p<0.01$, Table 2$)$. This observation is similar to that of Scalschi et al., who found increased amounts of salicylic acid in tomato $48 \mathrm{~h}$ after infection with P. syringae [28].

Table 2. Peak areas of extracted ion chromatograms (EIC) for compound putatively identified as a salicylic acid glucoside. Two m/z values (299.0772 and 359.0984) were merged into one chromatogram. Data are presented as means \pm standard deviations of three biological replicates. Statistical significance was determined using factorial ANOVA, different letters indicate significantly different results.

\begin{tabular}{cccc}
\hline \multirow{2}{*}{ Peak Area $(k$ Counts $\times \mathbf{s})$} & Young Plants & \multicolumn{2}{c}{ Old Plants } \\
\cline { 2 - 4 } & Young Leaves & Young Leaves & Old Leaves \\
\hline Control & $687 \pm 76(\mathrm{a})$ & $1372 \pm 26(\mathrm{a})$ & $1090 \pm 49(\mathrm{a})$ \\
Infected & $3661 \pm 123(\mathrm{~b})$ & $1867 \pm 89(\mathrm{a})$ & $1438 \pm 44(\mathrm{a})$ \\
\hline
\end{tabular}

\section{Materials and Methods}

\subsection{Chemicals, Plant, and Fungal Material Inoculation}

Phenolic acid standards were purchased from Sigma-Aldrich (caffeic, chlorogenic, ferulic, 4-hydroxybenzoic, and syringic acid, Darmstadt, Germany), Penta (benzoic acid, Prague, Czech Republic), and Cayman Chemicals (ellagic acid, Michigan, MI, USA).

Tomato plants (Solanum lycopersicum cv. Amateur) were grown in $25^{\circ} \mathrm{C}, 50 \%$ humidity and $16 \mathrm{~h}$ light period. Three types of leaves were inoculated with Pseudomonas syringae pv. tomato DC3000 (kindly provided by prof. Galaud, Université Paul Sabatier (Toulouse, France): young leaves (first and second fully developed from the top of the plant) from young plants (6.5 weeks old), young leaves from old plants (12 weeks old), and old leaves (fourth and fifth fully developed) from old plants. In total, three young and three old plants were used: a mixture of two leaves from one plant was considered a biological replicate. Inoculation was done by immersing the detached leaves into $P$. syringae suspension $\left(10^{7}\right.$ bacteria per $\mathrm{mL}$ ) with $0.0025 \%$ surfactant (Silwet, General Electric Company, Fairfield, Connecticut, $\mathrm{CT}$, USA). Control leaves were immersed into $0.0025 \%$ surfactant in water. Leaves were then kept in a wet place for two days, until they showed first disease symptoms. Afterwards, stems were removed, leaves from the same plant were mixed, and samples were kept at $-70{ }^{\circ} \mathrm{C}$ until analysis.

\subsection{Extraction and Analysis of Total Phenolic Contents}

Leaves were dried at $60^{\circ} \mathrm{C} .50 \mathrm{mg}$ of dry leaves were extracted twice with $1 \mathrm{~mL} 80 \%$ methanol by $1 \mathrm{~min}$ of vigorous mixing, $15 \mathrm{~min}$ of sonication, and $30 \mathrm{~min}$ of incubation $\left(750 \mathrm{rpm}, 25^{\circ} \mathrm{C}\right)$. The total content of phenolics was assessed using Folin-Ciocalteu reagent, which oxidizes the hydroxyl groups of phenols. Briefly, $50 \mu \mathrm{L}$ of Folin-Ciocalteu reagent was added to $100 \mu \mathrm{L}$ of the extract, and after three minutes, $100 \mu \mathrm{L}$ of sodium carbonate solution $(5 \mathrm{~g} / \mathrm{L})$ and $750 \mu \mathrm{L}$ of water were added. The mixture was incubated at $50{ }^{\circ} \mathrm{C}$ for $16 \mathrm{~min}$. Then, absorbance was measured at $765 \mathrm{~nm}$ and compared with that obtained from the blank (without Folin-Ciocalteu reagent). The calibration curve was prepared using gallic acid. The results obtained were thus expressed as $\mu \mathrm{g}$ of gallic acid equivalents per $1 \mathrm{~mL}$ of leaf extract, i.e., $25 \mathrm{mg}$ of dry leaves. Three biological replicates per condition were analyzed. 


\subsection{Analysis of Phenolic Profiles and Quantification of Phenolic Acids}

$1 \mathrm{~mL}$ of the leaf extract was heated to $50^{\circ} \mathrm{C}$, dried in a nitrogen stream, and dissolved in $1 \mathrm{~mL}$ of $5 \%$ methanol in acidic water (0.01\% acetic acid). Samples were filtered and analyzed by HPLC-MS (6545, Agilent, Santa Clara, CA, USA). Analytes were separated using a reverse-phase column (EclipsePlus $\mathrm{C} 18,2.1 \times 50 \mathrm{~mm}^{2}, 1.8 \mu \mathrm{m}$, Agilent, Santa Clara, CA, USA) and a gradient elution. The mobile phases used were (A) $0.01 \%$ acetic acid and (B) methanol. The gradient conditions were as follows: 5 to $20 \%$ B from 0 to $10 \mathrm{~min}, 20$ to $100 \%$ B from 10 to $20 \mathrm{~min}$, and finally, $100 \%$ from 20 to $30 \mathrm{~min}$, at a flow rate of $0.3 \mathrm{~mL} / \mathrm{min}$ and injection volume of $5 \mu \mathrm{L}$. Electrospray ion source was used under the following conditions: acquisition mode $100-1700 \mathrm{~m} / z$, gas temperature $300{ }^{\circ} \mathrm{C}$, gas flow $8 \mathrm{~L} / \mathrm{min}$, ion polarity negative, capillary voltage $4000 \mathrm{~V}$, fragmentor voltage $150 \mathrm{~V}$.

Phenolic compounds and compounds from biosynthetic pathways of phenolics were detected by TOF and putatively identified by comparing obtained mass spectra with the database (Metlin, The Scripps Research Institute, La Jolla, CA, USA, metlin.scripps.edu). Selected phenolic acids were identified by comparison of retention times and mass spectra with those of respective standards. Successfully identified analytes were quantified using peak areas of $[\mathrm{M}-\mathrm{H}]^{-}$ions (Table 3). Calibration curves were drawn using standards in MassHunter Quantitative Analysis software (Agilent, Santa Clara, CA, USA https://www.agilent.com/en/products/software-informatics/masshunter-suite/masshunterquantitative-analysis). Three biological replicates per condition were analyzed.

Table 3. $\mathrm{m} / \mathrm{z}$ ratios of the successfully identified analytes.

\begin{tabular}{cc}
\hline Analyte & {$[\mathbf{M}-\mathbf{H}]^{-}(\mathrm{m} / z)$} \\
\hline Benzoic acid & 121.0295 \\
Caffeic acid & 179.0350 \\
Ferulic acid & 193.0506 \\
4-hydroxybenzoic acid & 137.0244 \\
Syringic acid & 197.0455 \\
\hline
\end{tabular}

\subsection{Statistical Analysis}

Differences in total phenolic contents, concentrations of phenolic acids and peak areas for compound putatively identified as a salicylic acid glucoside were assessed using factorial ANOVA (the factors being infection and age). Due to unequal variances, concentrations of total phenolics, benzoic and ferulic acids were log-transformed before analysis. Tukey HSD test was used as a post-hoc test. The $p$-value cutoff for significant results was set to 0.05. Differences in phenolic profiles were visualized using principal component analysis (PCA) in Mass Profiler Professional 15.0 software (Agilent, Santa Clara, CA, USA, https:/www.agilent.com/en/product/software-informatics/ mass-spectrometry-software/data-analysis/mass-profiler-professional-software).

\section{Conclusions}

In young plants, the bacterial infection seems to cause the enhanced synthesis of salicylic acid glucoside from pre-formed benzoic acid. In old plants, the concentration of pre-formed benzoic acid is low; therefore, in the case of infection, no salicylic acid glucoside is synthesized. The data suggest that in the case of infection, benzoic acid is not newly produced, as carbon is redirected from the benzoic acid biosynthetic pathway through coumaric acid to antimicrobial caffeic, ferulic, and 4-hydroxybenzoic acids.

In older plants, differences can be seen between young and old leaves. Young leaves contain more ferulic acid and its precursor caffeic acid; therefore, they are supposedly better protected against bacterial infections than old leaves. However, the differences in the contents of phenolic acids, caused by a bacterial infection, are more subtle and statistically insignificant in old plants. Altogether, the data 
indicate that the responsiveness of several tomato phenolics to bacterial infection decreases with the plant age.

Supplementary Materials: The following are available online. Table S1: List of putatively identified compounds. Figure S1: Mass spectra of both correctly identified and misidentified phenolic acids.

Author Contributions: Conceptualization, K.D.; methodology, K.D., J.L., and T.K.; investigation, K.D. and T.H.; resources, T.K., K.D., and J.L.; formal analysis, K.D.; writing — original draft preparation, K.D.; writing—review and editing, T.K.; visualization, K.D.; supervision, K.D. and T.K. All authors have read and agreed to the published version of the manuscript.

Funding: This research was funded by the Grant Agency of Masaryk University: Support for biochemical research in 2020, grant number MUNI/A/1252/2019.

Acknowledgments: We thank Jean-Philippe Galaud, Université Paul Sabatier, who donated P. syringae DC3000 strain, and our colleague Vojtěch Sedláček, who donated caffeic acid used for our experiments.

Conflicts of Interest: The authors declare no conflict of interest. The funders had no role in the design of the study; in the collection, analyses, or interpretation of data; in the writing of the manuscript, or in the decision to publish the results.

\section{References}

1. Barriere, V.; Lecompte, F.; Lescourret, F. Efficacy of pest and pathogen control, yield and quality of winter lettuce crops managed with reduced pesticide applications. Eur. J. Agron. 2015, 71, 34-43. [CrossRef]

2. Zaynab, M.; Fatima, M.; Abbas, S.; Sharif, Y.; Umair, M.; Zafar, M.H.; Bahadar, K. Role of secondary metabolites in plant defense against pathogens. Microb. Pathog. 2018, 124, 198-202. [CrossRef] [PubMed]

3. Pott, D.M.; Osorio, S.; Vallarino, J.G. From Central to Specialized Metabolism: An Overview of Some Secondary Compounds Derived from the Primary Metabolism for Their Role in Conferring Nutritional and Organoleptic Characteristics to Fruit. Front. Plant Sci. 2019, 10, 835. [CrossRef] [PubMed]

4. Grassmann, J.; Hippeli, S.; Elstner, E.F. Plant's defence and its benefits for animals and medicine: Role of phenolics and terpenoids in avoiding oxygen stress. Plant Physiol. Biochem. 2002, 40, 471-478. [CrossRef]

5. Pereira, D.; Valentão, P.; Pereira, J.; Andrade, P. Phenolics: From Chemistry to Biology. Molecules 2009, 14, 2202-2211. [CrossRef]

6. Bhattacharya, A.; Sood, P.; Citovsky, V. The roles of plant phenolics in defence and communication during Agrobacterium and Rhizobium infection: Phenolics in Agrobacterium and Rhizobium infection. Mol. Plant Pathol. 2010. [CrossRef] [PubMed]

7. Pombo, M.A.; Zheng, Y.; Fernandez-Pozo, N.; Dunham, D.M.; Fei, Z.; Martin, G.B. Transcriptomic analysis reveals tomato genes whose expression is induced specifically during effector-triggered immunity and identifies the Epk1 protein kinase which is required for the host response to three bacterial effector proteins. Genome Biol. 2014, 15, 492. [CrossRef] [PubMed]

8. Pedley, K.F.; Martin, G.B. Molecular Basis of Pto-Mediated Resistance to Bacterial Speck Disease in Tomato. Annu. Rev. Phytopathol. 2003, 41, 215-243. [CrossRef]

9. Baker, C.J.; Owens, R.A.; Whitaker, B.D.; Mock, N.M.; Roberts, D.P.; Deahl, K.L.; Aver'yanov, A.A. Effect of viroid infection on the dynamics of phenolic metabolites in the apoplast of tomato leaves. Physiol. Mol. Plant Pathol. 2010, 74, 214-220. [CrossRef]

10. Pothinuch, P.; Tongchitpakdee, S. Phenolic Analysis for Classification of Mulberry (Morus spp.) Leaves according to Cultivar and Leaf Age. J. Food Qual. 2019, 2019, 2807690. [CrossRef]

11. Matsuki, M. Regulation of Plant Phenolic Synthesis: From Biochemistry to Ecology and Evolution. Aust. J. Bot. 1996, 44, 613. [CrossRef]

12. Babou, L.; Hadidi, L.; Grosso, C.; Zaidi, F.; Valentão, P.; Andrade, P.B. Study of phenolic composition and antioxidant activity of myrtle leaves and fruits as a function of maturation. Eur. Food Res. Technol. 2016, 242, 1447-1457. [CrossRef]

13. Çetinkaya, H.; Kulak, M. Relationship between total phenolic, total flavonoid and oleuropein in different aged olive (Olea europaea 1.) Cultivar leaves. Afr. J. Trad. Compl. Alt. Med. 2016, 13, 81. [CrossRef]

14. Luiz, C.; Rocha Neto, A.C.; Di Piero, R.M. Resistance to Xanthomonas Gardneri in Tomato Leaves Induced by Polysaccharides from plant or Microbial. J. Plant Pathol. 2015, 1. [CrossRef] 
15. Silva-Beltrán, N.P.; Ruiz-Cruz, S.; Cira-Chávez, L.A.; Estrada-Alvarado, M.I.; Ornelas-Paz, J.D.; López-Mata, M.A.; Del-Toro-Sánchez, C.L.; Ayala-Zavala, J.F.; Márquez-Ríos, E. Total Phenolic, Flavonoid, Tomatine, and Tomatidine Contents and Antioxidant and Antimicrobial Activities of Extracts of Tomato Plant. Int. J. Anal. Chem. 2015, 2015, 284071. [CrossRef]

16. Piao, X.-M.; Jang, E.-K.; Chung, J.-W.; Lee, G.-A.; Lee, H.-S.; Sung, J.-S.; Jeon, Y.-A.; Lee, J.-R.; Kim, Y.-G.; Lee, S.-Y. Variation in Antioxidant Activity and Polyphenol Content in Tomato Stems and Leaves. Plant Breed. Biotech. 2013, 1, 366-373. [CrossRef]

17. Arab, M.; Bahramian, B.; Schindeler, A.; Valtchev, P.; Dehghani, F.; McConchie, R. Extraction of phytochemicals from tomato leaf waste using subcritical carbon dioxide. Innov. Food Sci. Emerg. Technol. 2019, 57, 102204. [CrossRef]

18. Ratnavathi, C.V. Grain Structure, Quality, and Nutrition. In Breeding Sorghum for Diverse End Uses; Elsevier: Amsterdam, The Netherlands, 2019; pp. 193-207. ISBN 978-0-08-101879-8.

19. Widhalm, J.R.; Dudareva, N. A Familiar Ring to It: Biosynthesis of Plant Benzoic Acids. Mol. Plant 2015, 8, 83-97. [CrossRef]

20. Lefevere, H.; Bauters, L.; Gheysen, G. Salicylic Acid Biosynthesis in Plants. Front. Plant Sci. 2020, 11, 338. [CrossRef]

21. Kousar, B.; Bano, A.; Khan, N. PGPR Modulation of Secondary Metabolites in Tomato Infested with Spodoptera litura. Agronomy 2020, 10, 778. [CrossRef]

22. Kundu, A.; Mishra, S.; Vadassery, J. Spodoptera litura-mediated chemical defense is differentially modulated in older and younger systemic leaves of Solanum lycopersicum. Planta 2018, 248, 981-997. [CrossRef] [PubMed]

23. López-Gresa, M.P.; Payá, C.; Rodrigo, I.; Bellés, J.M.; Barceló, S.; Hae Choi, Y.; Verpoorte, R.; Lisón, P. Effect of Benzothiadiazole on the Metabolome of Tomato Plants Infected by Citrus Exocortis Viroid. Viruses 2019, 11, 437. [CrossRef] [PubMed]

24. Shi, C.; Zhang, X.; Sun, Y.; Yang, M.; Song, K.; Zheng, Z.; Chen, Y.; Liu, X.; Jia, Z.; Dong, R.; et al. Antimicrobial Activity of Ferulic Acid against Cronobacter sakazakii and Possible Mechanism of Action. Foodborne Pathog. Dis. 2016, 13, 196-204. [CrossRef]

25. Lima, V.N.; Oliveira-Tintino, C.D.M.; Santos, E.S.; Morais, L.P.; Tintino, S.R.; Freitas, T.S.; Geraldo, Y.S.; Pereira, R.L.S.; Cruz, R.P.; Menezes, I.R.A.; et al. Antimicrobial and enhancement of the antibiotic activity by phenolic compounds: Gallic acid, caffeic acid and pyrogallol. Microb. Pathog. 2016, 99, 56-61. [CrossRef]

26. González-Hernández, A.I.; Llorens, E.; Agustí-Brisach, C.; Vicedo, B.; Yuste, T.; Cerveró, A.; Ledó, C.; García-Agustín, P.; Lapeña, L. Elucidating the mechanism of action of copper heptagluconate on the plant immune system against Pseudomonas syringae in tomato (Solanum lycopersicum L): Effect of Cu-heptagluconate against Pseudomonas syringae in tomato. Pest. Manag. Sci. 2018, 74, 2601-2607. [CrossRef] [PubMed]

27. Aksoy, H.M.; Kaya, Y.; Ozturk, M.; Secgin, Z.; Onder, H.; Okumus, A. Pseudomonas putida—Induced response in phenolic profile of tomato seedlings (Solanum lycopersicum L.) infected by Clavibacter michiganensis subsp. michiganensis. Biol. Control 2017, 105, 6-12. [CrossRef]

28. Scalschi, L.; Llorens, E.; García-Agustín, P.; Vicedo, B. Role of Jasmonic Acid Pathway in Tomato Plant-Pseudomonas syringae Interaction. Plants 2020, 9, 136. [CrossRef] [PubMed]

Publisher's Note: MDPI stays neutral with regard to jurisdictional claims in published maps and institutional affiliations.

(C) 2020 by the authors. Licensee MDPI, Basel, Switzerland. This article is an open access article distributed under the terms and conditions of the Creative Commons Attribution (CC BY) license (http://creativecommons.org/licenses/by/4.0/). 